\title{
Influential factors in water planning for sustainable tourism destinations
}

\author{
Vila, M., Afsordegan, A., Agell, N., Sánchez, M., Costa, G.
}

\begin{abstract}
Many destinations are implementing various water management alternatives to diminish the environmental impacts of tourism and increase sustainability. These efforts toward sustainability can be understood as part of corporate social responsibility (CSR) strategies implemented by tourism destinations. This paper is focused on the tourism destination of the Costa Brava (Catalonia, Spain) and describes a method for selecting a list of influential factors in water management for sustainable tourism destinations by considering stakeholder preferences for technical, economic, social, political, and environmental factors. A new qualitative Delphi technique is used to identify a set of qualitative and quantitative factors by surveying eight stakeholders (six water management experts and two hotel managers). In addition, the study presents the weight for each of the influential factors that decision makers - water planners, policy makers, tourism destination managers and hotel managers - can use in assessing water management alternatives. Although research to date has addressed many aspects of responsible tourism, there is little literature on the importance of water management in responsible strategies for tourism destinations. This paper contributes to a more efficient implementation of CSR strategies in tourism destinations by proposing a new methodology for identifying key factors for assessing sustainable solutions for water problems.
\end{abstract}

Keywords: Corporate social responsibility, sustainable tourism destination, qualitative Delphi, water management

\section{Introduction}

Tourism destinations have begun to prioritise sustainable growth rather than just economic growth. These destinations are including activities and strategies to increase sustainability as part of their corporate social responsibility (CSR) strategies (Gössling, Ring, Dwyer, Andersson \& Hall, 2015). Water management has become a key area to ensure sustainability for tourism destinations, and managers must handle some of the environmental drawbacks caused by tourism - including water and energy consumption and waste (Aall, 2011; Bramwell \& Lane, 1993; Chan \& Lam, 2003).

The research presented in this paper deals with water management and is focused on the Costa Brava. The Costa Brava, located in the north-eastern corner of the Mediterranean in the 
Spanish region of Catalonia, is one of Spain's main tourism destinations during the summer months (when the population between June and August increases fourfold). The resident population of the area is estimated at 250,000 inhabitants and can reach over one million in summer. Tourism is the main socio-economic activity in the region and more than $65 \%$ of beds correspond to hotels and second homes. This is a pattern that can be found in other Spanish and European tourist areas (Salo, Garriga, Rigall-I-Torrent, Vila \& Fluvia, 2014). The Costa Brava has limited water resources and so management is a major challenge for the government and water companies, especially during the hot dry summer months when tourists arrive. Seawater intrusion into groundwater aquifers limits the ability of municipalities to meet water demand by inter-basin transfer from neighbouring river basins. The crucial concerns include insufficient water supply to meet growth trends and poor water quality. Burns (2013) performed a comprehensive sustainability assessment of water supply in two villages in the Costa Brava, Lloret de Mar and Tossa de Mar (both of which became important tourism destinations in the 1960s). The study concluded that aggressive conservation and education campaigns could produce a $20 \%$ savings in water consumption. However, these savings are considered insufficient; and so alternative measures are needed to ensure a sustainable water supply.

The Costa Brava Consortium (CCB) is a public water utility created in 1971 by the 27 coastal municipalities in the province of Girona to provide services and manage infrastructures for the whole water cycle, including drinking water, wastewater treatment, and the production and supply of reclaimed water for covering non-potable demands (www.ccbi.org). The CCB must decide which measures have to be taken after considering energy and investment costs, as well as social or environmental factors. One of the measure used since 1989 is the reclamation of treated effluent to meet non-potable demands (such as aquifer recharge, farm irrigation, golf course and landscape watering, and municipal reclaimed water networks).

From a sustainability point of view, finding a solution for water management involves a multi-criteria decision analysis to select the relevant factors and assess the possible solutions or scenarios. A research project has been defined in two parts for extracting indicators and assessing scenarios: the first part of the analysis and results (which are presented in this paper) suggests a new qualitative Delphi method to select the relevant indicators by integrating both sustainable tourism management (mostly qualitative) and water management (mostly quantitative) with a focus on stakeholder points of view. The second part of the project (which is beyond the scope of this paper) consists of evaluating scenarios to find the best solution with respect to the indicators obtained from the previous step.

The Delphi technique, first introduced by Dalkey \& Helmer (1963), is a well-known group decision-making method for reaching consensus among a panel of experts or stakeholders on the significant features of a certain topic. This technique helps generate opinions and build consensus (Miller, 2001). The proposed qualitative Delphi method offers a flexible qualitative scale that enables experts to indicate their opinions, even under conditions of uncertainty, using linguistic variables. A survey has been performed that considers qualitative and quantitative factors from the literature to select the most important factors and assign weight to each. This information can then be used to support decision makers in the tourism destination (i.e. water planners, policy makers, and hotel managers).

Although research to date has addressed many aspects of CSR and responsible tourism, there is little literature on the importance of water management in responsible tourism strategies for destinations. This paper contributes to more efficient implementations of CSR strategies in 
tourism destinations by proposing a methodology to identify the most influential factors to support decision makers in selecting sustainable solutions for water problems.

The next section reviews existing literature on responsible tourism with the focus on water management and presents an in-depth study of the main factors or indicators in the literature related to this topic. A new qualitative Delphi method for selecting qualitative and quantitative factors is then introduced. The section entitled 'A real case application to the Costa Brava' presents an application of the proposed method. In the final section, conclusions are drawn and suggestions made for further work.

\section{Background}

\section{Water management as part of tourism destination CSR}

According to Carroll (1979), the CSR framework has been applied to tourism as a form of sustainability and has been discussed in the literature for more than a decade (Coles, Fenclova \& Dinan, 2013; Dodds \& Joppe, 2005). The significance of CSR for tourism and destinations has recently increased with the adoption of various socially responsible activities in response to customer demands (Dodds \& Kuehnel, 2010). Such activities are voluntary and aimed at some social benefit beyond what is required by law and the interests of the firms. CSR is not an homogeneous idea, but rather a multi-faceted concept and it is sometimes just a more formal term for responsible business (Hawkins \& Bohdanowicz, 2012). Today, the terms sustainable and responsible are commonly used in the context of socio-economic development. However, the meaning of sustainability has become fuzzy, and is increasingly used as a rhetorical justification for anthropocentric development.

For Frey and George (2010), for instance, a responsible approach may include attempts to increase community involvement in decision-making, provide employment opportunities, revise investment policies and relations with investors, comply with governmental regulations, reduce waste, and increase management of scarce natural resources. These types of activities are compatible with most orthodox definitions of CSR. Other activities may include: the exercise of good business ethics (Coughlan, 2001; Yaman \& Gurel, 2006); pro-poor tourism and poverty alleviation (Hall, 2007; Scheyvens, 2007); voluntary initiatives such as codes of conduct (Dodds \& Joppe, 2005); certification schemes (Bendell \& Font, 2004; Font \& Harris, 2004); environmental measures (Blanco, Rey-Maquieira \& Lozano, 2009); and responsible or 'green' marketing (Dief \& Font, 2010; Hudson \& Miller, 2005).

The merits of CSR have been endorsed by many tourism businesses, intermediaries, trade associations, lobbying groups, and non-governmental organisations (Bohdanowicz \& Zientara, 2009; Dodds \& Joppe, 2005). Engaging in CSR has many positive impacts on a business or destination and may act as 'brand insurance' (Werther \& Chandler, 2005). In the tourist industry, CSR has mainly been implemented by intermediaries (e.g. tour operators), trade associations, and non-governmental organisations. However, CSR has not yet been widely discussed at the level of destinations.

An ecological perspective usually provides the main objectives for sustainable tourism development as the environment is often a critical limiting factor. There is a need to preserve natural resources by reducing the ecological impact of tourist activities. The ecological dimension is described as the 'most important source for a touristic development' and it may 
include the reduction of resource consumption, or the avoidance of negative impacts on biodiversity (Tekken \& Kropp, 2015). Water is one of the resources to be considered within this perspective for two reasons: firstly, supply in many destinations cannot satisfy the demand of all sectors; and secondly, tourism is a water consumer that could foster a constant water shortage crisis unless countermeasures are taken (Cashman \& Moore, 2012).

Tourism is dependent on water resources and is an important factor in water use. Tourists need and consume water (personal hygiene and laundry, ski or golf tourism, spas, wellness areas, swimming pools, maintaining gardens and landscaping of hotels and attractions, etc.) (Gössling, 2001). Moreover, tourism depends on the availability of water, as changes in the availability or quality of water, or the lack of water may affect the image of tourism destinations. A shortage of water can also generate enormous costs for the restoration of ecosystems. A critical water situation is a real limiting factor that could affect the commercial success, efficiency, and competitiveness of regional tourism (Gössling, Peeters, Hall, Ceron, Dubois, Lehmann \& Scott, 2012).

As described by Gössling (Gössling et al., 2012), in the last 50 years global water use has tripled. Water stress affects a large part of humanity, with an estimated 450 million people already living under severe water stress in 1995. An additional 1.4e2.1 billion people live in water-stressed basins in northern Africa, the Mediterranean region, the Middle East, the Near East, southern Asia, northern China, Australia, the USA, Mexico, north eastern Brazil and the west coast of South America. These numbers underline the importance of water management for humanity. In this context, tourism is only relevant in a few countries as a significant factor in national water use as agricultural or industrial uses are much more important in a general analysis. However, the situation can be dramatically different when water demand is concentrated in time and space, and when trends in water consumption are considered. Tourism is a significant factor in water use, especially when water demand is concentrated in time and space. It may contribute to improvements in water quality (sewage treatment systems that also process local wastewater, or treatment systems to improve local water quality to meet tourist expectations). However, in most regions, tourism appears to worsen water quality.

The use of water by the tourism industry is likely to increase with increased tourist numbers, higher hotel standards, and increasingly water-intense tourist activities. Further, water demand is also likely to increase due to climate change and its consequences for water availability. Therefore, tourism in many regions will probably face poor quality water and shortages. Some authors call for a critical assessment of tourism water use and for broad water management measures for tourism, especially in dry regions (Gösling et al, 2012; Gabarda, Ribas, Daunis-i-Estadella, 2015).

The efficient management of water resources is key to ensuring the sustainability of tourism destinations. Generally, water management can be based on two policies: demand management or supply management. As described by Wolfe and Brooks (2017) demand management policies focus on lowering demand and making existing supply go further. Planners use pricing, technology, and information programmes to improve water-use efficiency and optimise existing infrastructure. The outcome of these policies are efficiency gains through pricing, technical enhancements, and consumer education. The success of demand management policies vary because proposing an increase in water rates loses votes in elections, and because there is a conflict of interests between trying to sell enough water to meet financial objectives and promoting water conservation. Supply management policies have been the traditional response to water scarcity and have produced large profits for water supply companies - but they 
usually generate adverse consequences for natural resources. Planners estimate future requirements of water, and then locate and develop new sources of supply to meet this demand by building dams, pipelines, canals, wells, desalination systems, and so on. The solution to achieving sustainable water security may be neither demand nor supply management policies, but a more radical soft-path paradigm (Brooks, Brandes \& Gurman, 2009; Gleick, 2003). This approach consists in identifying policies and actions to achieve equitable access to sustainable water resources. Planners model a sustainable future state for water use considering long-term economic and social prosperity - and aim to reduce water use through innovation, conservation, and reuse.

Various technical options are available to increase available water supply capacities. For instance, prospecting and extracting groundwater can supply additional water in situations where sufficient water resources are available, while further attention can be given to recycling water for non-potable urban uses such as toilet flushing (Lazarova, Hills \& Birks, 2003). Desalination might be another option to enhance water resources in some areas and has contributed to a better standard of living in numerous countries during the second half of the 20th century. However, there are several effects to be considered in desalination plants - such as the use of the land, aquifer contamination due to the seawater pipe leaks, noise pollution, increased energy consumption (desalination plants can use $3 \mathrm{e} 12.5 \mathrm{kWh}$ of electricity), as well as additional emissions of greenhouse gases (of around $1 \mathrm{e} 10 \mathrm{~kg} \mathrm{CO} 2$ per $\mathrm{m} 3$ of water). In addition to these costs and negative effects, there is the concern about using desalination when demand management could be more effective (Gude, Nirmalakhandan \& Deng, 2010; Sadhwani, Veza \& Santana, 2005).

Considerable differences exist between the most important tourism countries in renewable water resources, desalination capacity, use of treated wastewater, and water use (and specifically, tourism water use). In some countries, water use exceeds renewable water resources by up to a factor of 15, while in other countries, such as Spain, a significant share of renewable water is used. The 2005 Spanish National Hydrological (A.G.U.A) Plan encourages increased construction of desalinisation and water reuse treatment facilities (Burns, 2013). The same trend can be seen in Catalonia's regional water management plan. The Catalan Water Agency reported that $60 \%$ of urban water use comes from groundwater sources. The Costa Brava is considered to be one of the most popular destinations with natural sources (Mundet \& Ribera, 2001; Hadjikakou, Chenoweth \& Miller, 2013).

\section{Study of indicators in water management \& sustainable tourism}

Sustainable water planning and the sustainable development of tourism destinations have been the subjects of inclusive discussion. An analysis of influential factors or indicators can facilitate the design of advanced solutions for the planning and management of sustainable tourism in different areas (Chan \& Lam, 2003). In this section, we focus on the relevant indicators, firstly, regarding water management in tourism destinations; and secondly, regarding sustainable tourism management.

Decisions on water management based on a series of measures in a tourist area is a complex problem involving multiple criteria and aspects (Minatour \& Bonakdari, 2016). According to Minatour \& Bonakdari (2016), to optimise water utilisation and reduce damage caused by non-availability of water, various aspects should be considered and with differing 
degrees of importance. For example, aspects such as the behaviour of tourists may be relevant for demand side policies; but the cost of infrastructure may be much important for supply management. Therefore, the application of the traditional cost-benefit concept is not, on its own, enough for making decisions on water management. Decisions on these issues are related to several attributes that have different characteristics - and some of which are difficult to measure and evaluate by numerical values because they involve large amounts of information and their qualities are associated with uncertainty. Therefore, to evaluate the importance of all these attributes, the opinions of different experts must be explored. In this research, both types of factors or indicators are considered: numerical indicators (that can be measured using information of the city or cost-benefit models); and qualitative indicators.

Regarding water management studies in touristic areas, evidence suggests that quantitative indicators are mostly used to assess different scenarios. For instance, in the study by Gössling (2015), conventional water indicators were reviewed for resort hotels and other facilities while considering the complexities of direct and indirect water consumption. The study suggested eight new indicators to better capture sustainable water management: water availability (one indicator); infrastructure planning (three indicators); and operational processes (four indicators). In addition, many studies have considered specific sustainable indicators in water planning (Chen et al., 2012; Rahman et al., 2015; Straton, Jackson, Marinoni, Proctor \& Woodward, 2010; Toosi \& Samani, 2014). Most studies used the most common indicators found in the literature (e.g. investment and operational cost, energy consumption, and environmental impacts); but there are several studies of relevant sustainable indicators based on expert opinions - with the focus on specific tourism destinations (Ghasemi \& Hamzah, 2014; Toosi \& Samani, 2014). Toosi \& Samani (2014) indicated that different criteria for evaluating water transfer projects are classified in economic, social-cultural, and environmental clusters. These criteria include employment and migration, cost-benefit ratios, crisis management, and environmental impacts. However, in the study by Ghasemi \& Hamzah (2014), indicators are more detailed and consider the categorisation of political, social, cultural, economic, and environmental aspects.

Sustainable tourism indicators are fundamentally about integrating the economic perspective of tourism into an environmental and socio-cultural context. Over the last few years, numerous indicators have been created for tourism destinations, albeit with different objectives, perspectives, dimensions, and foci (Manning, 1999; Miller, 2001; WTO, 2004; Choi \& Sirakaya, 2006). Some authors have focused the debate on deciding and structuring the dimensions to be included in a comprehensive set of indicators. Some suggest the addition of political, technological, and cultural dimensions to the economic, environmental, and social dimensions (Ko, 2001; Choi \& Sirakaya, 2006) or classifying the type of indicators (process, input, or result indicators). Other research has focused on the purpose of the indicators: evaluating and monitoring the implementation of strategies, strategic planning, and management of destinations or evaluating the competitiveness of tourism destinations (Castellani \& Sala, 2010; Mihalič, 2000, among others). There is also literature about methodologies to determine the indicators for a specific area based on stakeholder points of view; for example, Tsaur, Lin \& Lin (2006) used the Delphi technique to identify the indicators and their priority weights to evaluate a sustainable ecotourism system; or Yasarata, Altinay, Burns \& Okumus (2010) used in-depth interviews and participant observation; while Choi \& Sirakaya (2006) used a modified Delphi technique to extract dimensions for community tourism development at local and regional levels. 
The study of indicators in sustainable tourism management (which are both quantitative and qualitative indicators) and water management in tourism destinations (which are mostly quantitative indicators) has shown that the integration of the relevant indicators in both contexts with a focus on stakeholder points of view has not been commonly investigated. Much research to date has addressed various approaches for managing water resources (Del Vasto-Terrientes, Kumar, Chao \& Valls, 2015; Kalbar, Karmakar \& Asolekar, 2013; Kelly \& Williams, 2007; Kuo \& Chen, 2009; Tsoutsos, Drandaki, Frantzeskaki, Iosifidis \& Kiosses, 2009), but there is a gap between the research on quantitative and qualitative studies of tourist-related indicators for evaluating different scenarios. In the present study, both quantitative and qualitative indicators are obtained by a thorough review of the relevant literature and discussion with experts in various fields. The proposed qualitative Delphi model based on an interval qualitative scale, introduced in the following section, may help stakeholders to deal with uncertainty in their responses.

\section{Method}

\section{An introduction to Delphi technique with linguistic variables}

The process of selecting relevant indicators involves establishing stakeholder preferences. There are effective tools such as qualitative models that can be helpful in providing a suitable method for identifying feasible evaluation indicators. Some of these tools are based on the rationale that a group of experts is better than one expert when precise knowledge is unavailable (Kaynak \& Macauley, 1984, Alonso, Herrera-Viedma, Chiclana \& Herrera, 2010). These techniques require dealing with uncertainty to reach consensus among a group of experts. Moreover, more flexible scales based on linguistic terms are appropriate to overcome the ambiguity existing in human knowledge that can be applied in different planning problems (Choudhury, Shankar \& Tiwari, 2006). The combination of such consensual approaches with linguistic variables is helpful for solving water resource management problems. This study proposes a new integrated qualitative Delphi method using linguistic variables (Q-Delphi).

The classic Delphi method described by Dalkey \& Helmer (1963) is a qualitative and structured technique for refining group judgments by reaching consensus among experts. This technique has the advantage of being able to generate opinions and move toward consensus (Miller, 2001). One of the main limitations of the classic Delphi method is the difficulty in dealing with the uncertainty involved in expert opinions, and the way in which some opinions are suppressed during the process of forming a consensus. These limitations can be addressed using linguistic variables that can be presented in the form of fuzzy linguistic terms (Herrera \& Herrera-Viedma, 2000; Dubois, HadjAli \& Prade, 2003; Aliev \& Pedrycz, 2013) or qualitative linguistic terms (Agell, Sánchez, Prats \& Roselló, 2012). The scale that has traditionally been used in Delphi questionnaires is a Likert scale. However, in the process of extracting information from expert points of view, the Likert scale sometimes makes it difficult for experts to present their opinion under uncertain situations or imperfect knowledge. Linguistic scales or fuzzy scales, in contrast, can represent uncertainty and handle vague situations when an expert lacks sufficient knowledge or certainty about his/her response. These scales can also be used as systematic tools for sustainability assessment. Several environmental management studies have used fuzzy scales (Liu, 2007; Tsoutsos et al., 2009) and qualitative linguistic terms (Afsordegan, 
Agell, Sanchez, Gamboa \& Cremades, 2014; Afsordegan, Sánchez, Agell, Zahedi \& Cremades, 2016) to help planners and policy makers design strategies.

The fuzzy Delphi method introduced by Murray, Pipino, and Gigch (1985) and extended by Kaufmann and Gupta (1988) also uses a fuzzy scale by means of triangle membership functions to achieve consensus among pessimistic, moderate, and optimistic expert assessments in different rounds of the Delphi process. These approaches enable experts to use linguistic labels, but they have a drawback in that they are unable to handle different levels of precision in their assessments, nor achieve a degree of consensus (Agell, Van Ganzewinkel, Sánchez, Roselló, Prats \& Andriessen, 2015). To overcome these drawbacks, we apply a linguistic model with absolute order-of-magnitude qualitative labels in the Delphi process. Qualitative reasoning (QR) develops systems that enable operating in conditions of insufficient or no numeric data. These techniques capture many features of human common sense reasoning. Several authors have extended these techniques to encompass reasoning about quantity orders-of-magnitude. Agell et al. (2015) offers the use of linguistic terms based on qualitative absolute order-ofmagnitude models in the Delphi process to reach consensus automatically - without a moderator nor a final interaction among panellists.

\section{The proposed modified Delphi method}

This paper proposes a new integrated method of applying qualitative linguistic terms to the challenge of assessing water resource planning. Based on Agell et al. (2015), in which an initial consensus model for Delphi processes with linguistic terms was introduced, we define a new measure of consensus among a set of expert opinions that considers both the linguistic terms used by the experts and their precision. Linguistic modelling used in the proposed method has the following advantages:

- offers an adequate scale for dealing with conflicting concepts (sustainable development is a multi-dimensional concept in social, ethical, technical, and environmental terms).

- considers intensity of preferences and gives experts the ability to respond with uncertainty by expressing their judgments using linguistic variables involving qualitative labels.

- enables multi-granular linguistic information to be expressed in a unified linguistic domain without losing or misrepresenting information. It avoids mistakes made by experts forced to make more precise judgments than they are capable. It avoids loss of information that may happen when experts are forced to make less precise judgments than they are capable.

We considered an absolute order-of-magnitude model with five basic linguistic labels from 'not important' to 'extremely important' (see Table 1).

[Table 1 near here]

The proposed modified Delphi questionnaire assumed an ordinal scale using the linguistic terms: 'Not important, low importance, medium importance, very important, extremely important, and no idea'; corresponding to the basic labels " $B_{1}, B_{2}, B_{3}, B_{4}, B_{5},\left[B_{1}, B_{5}\right]$ ", respectively. In addition, to deal with uncertainty and ambiguity, experts could answer the 
questionnaire using interval basic and non-basic labels. This means that when they were unsure about the importance of an indicator, they could choose a range of options, and even in the case that they had no idea, they could mark the interval from one to five. Moreover, experts were asked about the level of confidence in their responses: sure (1) or not sure (0). When an expert chose, for instance, 'medium importance' which is $B_{3}$ and 'not sure', we transformed it to the non-basic label $\left[B_{2}, B_{4}\right]$ meaning 'between low importance and very important'; and when an expert chose 'between low importance and medium importance' which is $\left[B_{2}, B_{3}\right]$ and 'not sure', we transformed it to the non-basic label $\left[B_{1}, B_{4}\right]$ meaning 'between not important and very important'. This last additional step, consisting of the translation of the answers into wider intervals, enables us to capture hesitancy when an expert was unsure about his/her answer.

When an expert is sure about his/her response, he/she can use an exact basic label and the level of confidence 'sure'; for example, 'very important' corresponds to the $\mathrm{B}_{4}$ basic label and (1). If the expert is unsure, or prefers to choose more than one option, he/she can use both nonbasic labels, such as 'medium importance-very important' which corresponds to $\left[B_{3}, B_{4}\right]$, and the confidence level 'unsure'. Even if the expert does not have an opinion about a question, he/she can choose $\left[B_{1}, B_{5}\right]$, which is considered the 'unknown' label. Thus, the proposed method considers different levels of granularity from the basic labels $B_{1}, \ldots, B_{5}$, which are the most precise labels, with a length of one, to the least precise label $\left[B_{1}, B_{5}\right]$, with a length of five. The complete set of linguistic labels with a granularity of five is the set denoted by $\left\{\left[B_{i}, B_{j}\right] \mid\right.$ $i, j=1, \ldots, 5\}$, where $\left[B_{i}, B_{i}\right]=B_{i}$. This structure, consisting of 15 different labels (see Figure 1 ), enables working simultaneously with different levels of precision.

[Figure 1 near here]

Two concepts are needed to express the measure of consensus that is used in this paper: the length of the connected union and the qualitative median. The union of two labels $\left[B_{i}, B_{j}\right]$ and $\left[B_{k}, B_{m}\right]$ is the label $\left[B_{i}, B_{j}\right] \sqcup\left[B_{k}, B_{m}\right]=\left[B_{\min (i, k)}, B_{\max (j, l)}\right]$ (for instance, $B_{1} \sqcup\left[B_{3}, B_{4}\right]=\left[B_{1}, B_{4}\right]$ with a length of four). The qualitative median of a set of labels ordered using the lexicographical order is the central label when there is an odd number of labels, and the union of the two central labels when the number of labels is even.

Once the qualitative labels have been introduced, the Q-Delphi method proposed in this paper is detailed through the following steps.

1- Extracting the initial relevant indicators: an initial set of relevant indicators is extracted from a literature review and by asking experts about their preferred indicators in a first round.

2- Using linguistic variables to assess indicators in a second round: experts use linguistic basic and non-basic labels to present their opinions about the importance of indicators in the area.

3- Ordering indicators: the list of indicators have been ordered using two criteria: first, the qualitative median; and second, the length of the union among the expert assessments. This order has been performed imposing the higher qualitative median and the lesser length of the union among qualitative assessments as a measure of a degree of consensus among the expert opinions. 
4- Selecting indicators: from among the list of ordered indicators, those with a qualitative median of at least $\left[B_{3}, B_{5}\right]$ are selected. This corresponds to a basic consensus as a certain percentage of the assessments fall within a prescribed range.

5- Weighting indicators: following the four previous steps, it is also possible to determine the indicator weights. The appropriate method for weighing indicators from their order is the Borda-Kendall approach. Borda-Kendall, initially proposed in Borda (1784) and adapted by Kendall's solution in 1961, is the most common decision-making procedure for obtaining a consensus arrangement. Once the indicators have been ordered by importance, the indicator weight $x_{i}$ is obtained using Eq. 1.

$w_{i}=\frac{2(n+1-i)}{n(n+1)}, \quad i=1, \ldots, n$

where $n$ is the total number of selected indicators from step 4 , thus, $\sum w_{i}=1$ and $w_{i} \in[0,1]$.

Note that the use of non-basic labels in Step 2 and the order defined in Step 3 enable the assessments given by the experts to include different levels of precision and the management of these assessments.

This integration of qualitative labels into the Delphi technique provides an appropriate method for selecting important indicators of stakeholder points of view. The following application shows the potential of the proposed method. It has been used to find the influential sustainable indicators for water resource planning in the Costa Brava.

\section{A real application to the Costa Brava}

We apply in this section the Q-Delphi method presented. Some indicators, as shown in the first step, were extracted from the literature and from a discussion with CCB experts. These indicators are relevant to sustainable water management in different areas, with the focus on tourist perceptions of destinations. They are related to technical, economic, environmental, social, and political aspects of sustainability in water management. From this first round, 33 indicators were selected. Table 2 presents these initial indicators.

\section{[Table 2 near here]}

In the second step, a survey was conducted with expert panel members. Eight experts in tourism and water management and hotel managers from CCB answered a questionnaire about the importance of qualitative and quantitative indicators for sustainable water planning. The questionnaire was sent to them by email and the questions were: 'What is your opinion about the importance of these aspects when making decisions about various alternatives for water management? What is the level of confidence about your answer (sure or not sure)? If there is any aspect that would add to the list that we offer, please indicate in the space provided'.

According to expert responses in the questionnaire, we performed steps three and four as introduced in the previous section to rank the list of 33 indicators. As stated before, the main idea underlying the ranking construction is that the higher the qualitative median and the higher the degree of consensus among experts, the more important is the indicator. For instance, investment cost, with the highest median and the shortest union, shows the highest degree of 
consensus among experts and is the most important indicator (see Table 3). However, there is a conflict among the expert opinions about the availability of financial support (see Table 3 ).

[Table 3 near here]

After ordering the indicators, the factors with a median greater than or equal to $\left[B_{3}, B_{5}\right]$ were selected (20 out of 33 ) and 13 remaining indicators were eliminated (see Table 4). All selected indicators have the median within the range of 'important' to 'extremely important' (a median greater than or equal to $\left.\left[B_{3}, B_{5}\right]\right)$.

\section{[Table 4 near here]}

The weights of indicators have been obtained using the Borda-Kendall method (step 5 in the previous section). Table 4 shows the final list of factors selected in various rounds of answering questions by the group of panellists and technicians - together with the weights calculated using Eq. 1. These weights will be used to rank alternatives in a multi-criteria decision-making tool designed to support municipalities in sustainable water planning.

The selected influential sustainable indicators and their weights can be used to assess various solutions or scenarios proposed by the CCB. Four scenarios will be presented for additional water needed during the high water demand season: additional recycling of water; desalination; water transfer; or business as usual (current situation). To determine the best solution, these four scenarios will be evaluated with respect to the selected indicators and their weight, and ranked using multiple criteria decision-making methods.

\section{Discussion and conclusion}

Water management and planning has become crucial to any tourism destination as demand for water is likely to rise with increased tourist numbers, higher hotel standards, and increasingly water-intensive tourist activities. Furthermore, water demand is likely to increase due to climate change and its consequences for water availability. Tourism in many regions will probably face considerable problems of water availability and quality, affecting the success, efficiency, and competitiveness of the tourism sector. Solutions for managing water in tourism destinations that consider economic factors, as well as environmental and social factors, transform water management into a CSR relevant issue if they positively impact on society.

With the objective of integrating CSR into decision-making for sustainable tourism, we have proposed a new methodology to deal with economic, technical, environmental, and social factors when selecting among water management alternatives. The new integrated qualitative Delphi technique, called 'Q-Delphi', aims to capture stakeholder opinions about the importance of various indicators. It is based on linguistic modelling and the main advantage is that it offers an adequate scale to deal with conflicting concepts. As sustainable development is a multidimensional concept; the Delphi technique takes into account the intensity of preferences and gives experts the ability to respond with uncertainty and permits multi-granular linguistic information to be expressed in a unified linguistic domain without losing or misrepresenting information.

We used the Costa Brava case as water management in this area is a major challenge, especially during the summer, and because there is a particular public water utility (CCB) with 
the objective of providing services and managing infrastructures for the whole water cycle in the area, including drinking water, wastewater treatment, and the production and supply of reclaimed water for covering non-potable demands. The concerns in this area include a lack of water to meet growth trends and poor water quality. Measures such as water recycling and desalination are necessary to ensure a sustainable water supply. We asked experts to use this new methodology and give their opinion about the importance for sustainable water planning of a list of quantitative and qualitative indicators that included both sustainable tourism management and water management indicators. Twenty indicators were selected and ranked according to the opinions about their respective importance. Note that the final selection of indicators is a combination of both quantitative factors (energy consumption, investment and operational costs, and water losses) and qualitative factors (water quality, public health, tourist satisfaction, and public acceptance).

The list of selected indicators and the weights obtained with the new technique will assist in the assessment of the various solutions or scenarios proposed for a tourism destination. By having the different values for each indicator in each solution, it is possible to obtain a global result as a summary of all the relevant factors - and so a comparison between scenarios will be clear and easy. The implementation of the chosen solution for water management will result in a more sustainable and responsible management of tourism destinations.

\section{References}

Aall, C. (2011). Energy use and leisure consumption in Norway: An analysis and reduction strategy. Journal of Sustainable Tourism, 19(6), 729-745.

Afsordegan, A., Agell, N., Sanchez, M., Gamboa, G. \& Cremades, L. (2014). Using linguistic description with multi-criteria decision aid approaches in urban energy systems. BDC Journal-Bollettino Del Centro Calza Bini, 14, 285-300.

Afsordegan, A., Sánchez, M., Agell, N., Zahedi, S. \& Cremades, L. V. (2016). Decision making under uncertainty using a qualitative TOPSIS method for selecting sustainable energy alternatives. International Journal of Environmental Science and Technology, 13(6), 1419-1432.

Agell, N., Sánchez, M., Prats, F. \& Roselló, L. (2012) Ranking multi-attribute alternatives on the basis of linguistic labels in group decisions. Information Sciences, 209, 49-60.

Agell, N., Van Ganzewinkel, C. J., Sánchez, M., Roselló, L., Prats, F. \& Andriessen, P. (2015). A consensus model for Delphi processes with linguistic terms and its application to chronic pain in neonates definition. Applied Soft Computing Journal, 35, 942-948.

Aliev, R. \& Pedrycz, W. (2013). Fuzzy optimality based decision making under imperfect information without utility. Fuzzy Optimization and Decision Making and Decision Making, 12(4), 357-372.

Alonso, S., Herrera-Viedma, E., Chiclana, F. \& Herrera, F. (2010). A web based consensus support system for group decision making problems and incomplete preferences. Information Science, 180(23), 4477-4495.

Bendell, J. \& Font, X. (2004). Which tourism rules?: Green standards and GATS. Annals of Tourism Research, 31(1), 139-156.

Blanco, E., Rey-Maquieira, J. \& Lozano, J. (2009). Economic incentives for tourism firms to undertake voluntary environmental management. Tourism Management, 30(1), 112-122.

Bohdanowicz, P. \& Zientara, P. (2009). Hotel companies' contribution to improving the quality of life of local communities and the well-being of their employees. Tourism \& Hospitality Research, 9(2), $147-158$.

Borda, J.C. (1784). Memoire sur les elections au scrutin. Historie de l'Academie Royale des Sciences, Paris. Available in McLean and Urken.

Bramwell, B. \& Lane, B. (1993). Interpretation and sustainable tourism: The potential and pitfalls. 
Journal of Sustainable Tourism, 1(2), 71-80.

Brooks, D. B., Brandes, O. M. \& Gurman, S. (2009). Making the most of the water we have: The soft path approach to water management. London: Earthscan/Routledge.

Burns, C. (2013). Report of Important Water-Energy Nexus Considerations: A sustainability Assessment of water supply in two municipalities of Costa Brava, Spain, 41.

Carroll, A. (1979). A three-dimensional conceptual model of corporate performance. Academy of Management Review, 4(4), 497-505.

Cashman, A. \& Moore, W. (2012). A market-based proposal for encouraging water use efficiency in a tourism-based economy. International Journal of Hospitality Management, 31(1), 286-294.

Castellani, V. \& Sala, S. (2010). Sustainable performance index for tourism policy development. Tourism Management, 31(6), 871-880.

Chan, W. W. \& Lam, J. C. (2003). Energy-saving Supporting Tourism Sustainability: A case of study of Hotel Swimming Pool Heat Pump.pdf. Journal of Sustainable Tourism, 11(1), 74-83.

Chen, Z., Ngo, H. H., Guo, W. S., Listowski, A., O'Halloran, K., Thompson, M. \& Muthukaruppan, M. (2012). Multi-criteria analysis towards the new end use of recycled water for household laundry: A case study in Sydney. Science of the Total Environment, 438, 59-65.

Choi, H. C. \& Sirakaya, E. (2006). Sustainability indicators for managing community tourism. Tourism Management, 27(6), 1274-1289.

Choudhury, A.K., Shankar R. \& Tiwari, M.K. (2006). Consensus-based intelligent group decisionmaking model for the selection of advanced technology. Decision Support System, 42(3) 1776-1799.

Coles, T., Fenclova, E. \& Dinan, C. (2013). Tourism and corporate social responsibility: A critical review and research agenda. Tourism Management Perspectives, 6, 122-141.

Coughlan, R. (2001). An analysis of professional codes of ethics in the hospitality industry. International Journal of Hospitality Management, 20(2), 147-162.

Dalkey, N. \& Helmer, O. (1963). An experimental application of the Delphi method to the use of experts. Management Science, 9(3), 458-467.

Del Vasto-Terrientes L., Kumar, V., Chao, T. C. \& Valls, A. (2016). A decision support system to find the best water allocation strategies in a Mediterranean river basin in future scenarios of global change. Journal of Experimental \& Theoretical Artificial Intelligence (JETAI), 28(1-2), 331-350.

Dief, M. \& Font, X. (2010). The determinants of hotels' marketing managers' green marketing behaviour. Journal of Sustainable Tourism, 18(2), 157-174.

Dodds, R. \& Joppe, M. (2005). CSR in the tourism industry? The status of and potential for certification, codes of conduct and guidelines. IFC/World Bank, Washington.

Dodds, R. \& Kuehnel, J. (2010). CSR among Canadian mass tour operators: good awareness but little action. International Journal of Contemporary, 22(2), 221-244.

Dubois, D., HadjAli, A. \& Prade, H. (2003). Making fuzzy absolute and fuzzy relative orders of magnitude consistent. Fuzzy Sets and Systems-IFSA, 694-701.

Font, X. \& Harris, C. (2004). Rethinking standards from green to sustainable. Annals of Tourism Research. 31(4), 986-1007.

Frey, N. \& George, R. (2010). Responsible tourism management: The missing link between business owners' attitudes and behaviour in the Cape Town tourism industry. Tourism Management, 31(5), 621-628.

Gabarda, A., Ribas, A. \& Daunis-i-Estadella, J. (2015). Desarrollo turístico y gestión eficiente del agua. Una oportunidad para el turismo sostenible en la Costa Brava (Girona). Investigaciones Turisticas, N9, 50-69.

Ghasemi, M. \& Hamzah, A. (2014). An Investigation of the Appropriateness of Tourism Development Paradigms in Rural Areas from Main Tourism Stakeholders' Point of View. Procedia - Social and Behavioral Sciences, 144, 15-24.

Gleick, P. H. (2003). Global freshwater resources: Soft-Path solutions for the 21 st century. Science, 302, $1524-1528$.

Gössling, S. (2001). The consequences of tourism for sustainable water use on a tropical island: 
Zanzibar, Tanzania. Journal of Environmental Management, 61(2), 179-191.

Gössling, S. (2015). New performance indicators for water management in tourism. Tourism Management, 46, 233-244.

Gössling, S., Peeters, P., Hall, C.M., Ceron, J.P., Dubois, G., Lehmann, L.V., Scott, D. (2012). Tourism and water use: Supply, demand, and security. An international review. Tourism Management, 33,1-15.

Gössling, S., Ring, A., Dwyer, L., Andersson, A.-C. \& Hall, C. M. (2015). Optimizing or maximizing growth? A challenge for sustainable tourism. Journal of Sustainable Tourism, 9582, 1-22.

Gude, V., Nirmalakhandan, N. \& Deng, S. (2010). Renewable and sustainable approaches for desalination. Renewable and Sustainable Energy Reviews, 14(9), 2641-2654.

Hadjikakou, M., Chenoweth, J. \& Miller, G. (2013). Estimating the direct and indirect water use of tourism in the eastern Mediterranean. Journal of Environmental Management, 114, 548-556.

Hall, C. (2007). Pro-poor tourism: who benefits?: perspectives on tourism and poverty reduction. Channel view publications.

Hawkins, R. \& Bohdanowicz, P. (2012). Responsible hospitality: theory and practice. Goodfellow Publishers.

Herrera, F. \& Herrera-Viedma, E. (2000). Linguistic decision analysis: steps for solving decision problems under linguistic information. Fuzzy Sets and Systems, 115(1), 67-82.

Hudson, S. \& Miller, G. (2005). The responsible marketing of tourism: the case of Canadian Mountain Holidays. Tourism Management, 26(2), 133-142.

Kalbar, P. P., Karmakar, S. \& Asolekar, S. R. (2013). The influence of expert opinions on the selection of wastewater treatment alternatives: A group decision-making approach. Journal of Environmental Management, 128, 844-851.

Kaufmann, A., Gupta, M.M. (1988). Fuzzy mathematical models in engineering and management science. North-Holland, Amsterdam.

Kaynak, E. \& Macauley, J. A. (1984). The Delphi technique in the measurement of tourism market potential: The case of Nova Scotia. Tourism Management, 5(2), 87-101.

Kelly, J. K. J. \& Williams, P. W. (2007). Modelling Tourism Destination Energy Consumption and Greenhouse Gas Emissions: Whistler, British Columbia, Canada. Journal of Sustainable Tourism, 15(1), 67-90.

Ko, T. G. (2001). Assessing progress of tourism sustainability. Annals of Tourism Research, 28(3), 817820.

Kuo, N.-W. \& Chen, P.-H. (2009). Quantifying energy use, carbon dioxide emission, and other environmental loads from island tourism based on a life cycle assessment approach. Journal of Cleaner Production, 17(15), 1324-1330.

Lazarova, V., Hills, S. \& Birks, R. (2003). Using recycled water for non-potable, urban uses: a review with particular reference to toilet flushing. Water Science and Technology, 3(4), 69-77.

Liu, K. F. R. (2007). Evaluating environmental sustainability: an integration of multiple-criteria decisionmaking and fuzzy logic. Environmental Management, 39(5), 721-36.

Manning, T. (1999). Indicators of tourism sustainability. Tourism Management, 20 (1), 179-181.

Mihalič, T. (2000). Environmental management of a tourism destination. Tourism Management, 21, 6578.

Miller, G. (2001). The development of indicators for sustainable tourism: results of a Delphi survey of tourism researchers. Tourism Management, 22(4), 351-362.

Minatour, Y. \& Bonakdari, H. (2016). Extension of Fuzzy Delphi AHP Based on Interval-Valued Fuzzy Sets and its Application in Water Resource Rating Problems. Water Resources Management, 30, 3123-3141.

Mundet, L. \& Ribera, L. (2001). Characteristics of divers at a Spanish resort. Tourism Management, 22(5), 501-510.

Murray, T.J., Pipino, L.L., Gigch, J.P. (1985). A pilot study of fuzzy set modification of Delphi, Human System Management, 5, 76-80. 
Rahman, M. A., Jaumann, L., Lerche, N., Renatus, F., Buchs, A. K., Gade, R., Sauter, M. (2015). Selection of the Best Inland Waterway Structure: A Multicriteria Decision Analysis Approach. Water Resources Management, 29(8), 2733-2749.

Sadhwani, J., Veza, J. \& Santana, C. (2005). Case studies on environmental impact of seawater desalination. Desalination, 185(1-3), 1-8.

Salo, A., Garriga, A., Rigall-I-Torrent, R., Vila, M. \& Fluvia, M. (2014). Do implicit prices for hotels and second homes show differences in tourists' valuation for public attributes for each type of accommodation facility? International Journal of Hospitality Management, 36, 120-129.

Scheyvens, R. (2007). Exploring the tourism-poverty nexus. Current Issues in Tourism, 10(2-3), 231-254.

Straton, A. T., Jackson, S., Marinoni, O., Proctor, W. \& Woodward, E. (2010). Exploring and Evaluating Scenarios for a River Catchment in Northern Australia Using Scenario Development, Multi-criteria Analysis and a Deliberative Process as a Tool for Water Planning. Water Resources Management, 25(1), 141-164.

Tekken, V. \& Kropp, J. (2015). Sustainable water management-perspectives for tourism development in north-eastern Morocco. Tourism Management Perspectives, 16, 325-334.

Toosi, S. L. R. \& Samani, J. M. V. (2014). A new integrated MADM technique combined with ANP, FTOPSIS and fuzzy max-min set method for evaluating water transfer projects. Water Resources Management, 28(12), 4257-4272.

Tsaur, S. H., Lin, Y. C. \& Lin, J. H. (2006). Evaluating ecotourism sustainability from the integrated perspective of resource, community and tourism. Tourism Management, 27(4), 640-653.

Tsoutsos, T., Drandaki, M., Frantzeskaki, N., Iosifidis, E. \& Kiosses, I. (2009). Sustainable energy planning by using multi-criteria analysis application in the island of Crete. Energy Policy, 37(5), $1587-1600$.

Werther, W. \& Chandler, D. (2005). Strategic corporate social responsibility as global brand insurance. Business Horizons, 48(4), 317-324.

Yaman, H. \& Gurel, E. (2006). Ethical ideologies of tourism marketers. Annals of Tourism Research, $33(2), 470-489$.

Yasarata, M., Altinay, L., Burns, P. \& Okumus, F. (2010). Politics and sustainable tourism development Can they co-exist? Voices from North Cyprus. Tourism Management, 31(3), 345-356.

Wolfe, S. E. \& Brooks, D. (2017) Mortality awareness and water decisions: a social psychological analysis of supply-management, demand-management and soft-path paradigms. Water International, 42 (1), 1-17.

WTO (2004). Indicators of Sustainable Development for Tourism Destinations. Madrid: OMT. 
Figure 1 - The complete set of linguistic labels

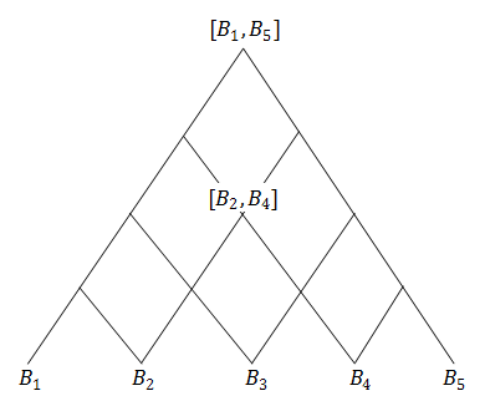

Table 1 - Linguistic label description

\begin{tabular}{ll}
\hline Basic labels & Linguistic basic labels \\
\hline$B_{1}$ & Not important \\
$B_{2}$ & Low importance \\
$B_{3}$ & Medium importance \\
$B_{4}$ & Very important \\
$B_{5}$ & Extremely important \\
\hline
\end{tabular}

Table 2 - Initial relevant indicators in sustainable water planning problem

\begin{tabular}{|c|c|c|c|c|}
\hline Technical & Economic & Environmental & Social & Political \\
\hline Water quality & Water cost & Environmental risk & Green image & $\begin{array}{l}\text { Consistency with } \\
\text { policies }\end{array}$ \\
\hline $\begin{array}{l}\text { Energy } \\
\text { consumption }\end{array}$ & $\begin{array}{l}\text { Refinery } \\
\text { cost }\end{array}$ & Land use & $\begin{array}{l}\text { Green } \\
\text { certification }\end{array}$ & $\begin{array}{l}\text { Range of conflict } \\
\text { among } \\
\text { stakeholders }\end{array}$ \\
\hline Water losses & $\begin{array}{l}\text { Investment } \\
\text { cost }\end{array}$ & Damage to lands & Job creation & $\begin{array}{l}\text { Political } \\
\text { acceptance }\end{array}$ \\
\hline \multirow[t]{7}{*}{$\begin{array}{l}\text { Simplicity of } \\
\text { construction }\end{array}$} & $\begin{array}{l}\text { Operational } \\
\text { cost }\end{array}$ & GHG emission & $\begin{array}{l}\text { Recreation } \\
\text { tourism }\end{array}$ & $\begin{array}{l}\text { Environmental } \\
\text { policy }\end{array}$ \\
\hline & $\begin{array}{l}\text { Financial } \\
\text { Support }\end{array}$ & Climate change & $\begin{array}{l}\text { Tourist } \\
\text { satisfaction }\end{array}$ & \\
\hline & $\begin{array}{l}\text { Return on } \\
\text { investment }\end{array}$ & $\mathrm{CO}_{2}$ Emission & Public health & \\
\hline & Job creation & GHG emission & Public acceptance & \\
\hline & & Ecological impact & Labour impact & \\
\hline & & & $\begin{array}{l}\text { Stakeholder } \\
\text { acceptance }\end{array}$ & \\
\hline & & & $\begin{array}{l}\text { Public security } \\
\text { and safety }\end{array}$ & \\
\hline
\end{tabular}


Table 3 - A part of the qualitative analysis table for economic criteria

\begin{tabular}{|c|c|c|c|c|c|c|c|c|c|c|}
\hline \multicolumn{11}{|c|}{ Economic Criteria } \\
\hline & $\begin{array}{l}\text { Return on } \\
\text { investment }\end{array}$ & $\begin{array}{l}\text { Sure/ } \\
\text { No }\end{array}$ & $\begin{array}{l}\text { Financial } \\
\text { Support }\end{array}$ & $\begin{array}{l}\text { Sure/ } \\
\text { No }\end{array}$ & $\begin{array}{l}\text { Operation } \\
\text { cost }\end{array}$ & $\begin{array}{l}\text { Sure/ } \\
\text { No }\end{array}$ & $\begin{array}{l}\text { Investment } \\
\text { cost }\end{array}$ & $\begin{array}{l}\text { Sure/ } \\
\text { No }\end{array}$ & $\begin{array}{l}\text { Water } \\
\text { cost }\end{array}$ & $\begin{array}{l}\text { Sure/ } \\
\text { No }\end{array}$ \\
\hline Expert 1 & $B_{3}$ & 1 & {$\left[B_{2}, B_{4}\right]$} & 0 & $B_{4}$ & 1 & $B_{4}$ & 1 & $B_{5}$ & 1 \\
\hline Expert 2 & $B_{4}$ & 1 & $B_{4}$ & 1 & $B_{5}$ & 1 & $B_{4}$ & 1 & $B_{1}$ & 1 \\
\hline Expert 3 & $B_{4}$ & 1 & $B_{4}$ & 1 & $B_{4}$ & 1 & $B_{4}$ & 1 & $B_{2}$ & 1 \\
\hline Expert 4 & $B_{3}$ & 1 & $B_{4}$ & 1 & $B_{4}$ & 1 & $B_{4}$ & 1 & $B_{4}$ & 1 \\
\hline Expert 5 & $B_{2}$ & 1 & {$\left[B_{1}, B_{3}\right]$} & 0 & $B_{3}$ & 1 & $B_{4}$ & 1 & $B_{4}$ & 1 \\
\hline Expert 6 & {$\left[B_{3}, B_{5}\right]$} & 0 & {$\left[B_{4}, B_{5}\right]$} & 0 & {$\left[B_{3}, B_{4}\right]$} & 0 & $B_{4}$ & 1 & {$\left[B_{3}, B_{5}\right]$} & 0 \\
\hline Expert 7 & $B_{4}$ & 1 & $B_{4}$ & 1 & $B_{4}$ & 1 & $B_{4}$ & 1 & $B_{5}$ & 1 \\
\hline Expert 8 & $B_{5}$ & 1 & $B_{5}$ & 1 & $B_{5}$ & 1 & $B_{5}$ & 1 & $B_{5}$ & 1 \\
\hline $\begin{array}{l}\text { Qualitative } \\
\text { median }\end{array}$ & {$\left[B_{3}, B_{5}\right]$} & & $B_{4}$ & & $B_{4}$ & & $B_{4}$ & & $B_{4}$ & \\
\hline $\begin{array}{l}\text { Connected } \\
\text { union }\end{array}$ & {$\left[B_{2}, B_{5}\right]$} & & {$\left[B_{1}, B_{5}\right]$} & & {$\left[B_{3}, B_{5}\right]$} & & {$\left[B_{4}, B_{5}\right]$} & & {$\left[B_{1}, B_{5}\right]$} & \\
\hline
\end{tabular}

Table 4 - Final order of indicators and their weights

\begin{tabular}{lllll}
\hline Indicators & $\begin{array}{l}\text { Qualitative } \\
\text { median }\end{array}$ & $\begin{array}{l}\text { length connected } \\
\text { union }\end{array}$ & Orders & Weights \\
\hline Water quality & $B_{5}$ & 4 & 1 & 0.095238 \\
Energy consumption & {$\left[B_{4}, B_{5}\right]$} & 3 & 2 & 0.090476 \\
Investment cost & $B_{4}$ & 1 & 3 & 0.085714 \\
Water losses & $B_{4}$ & 2 & 4 & 0.080952 \\
Operational cost & $B_{4}$ & 3 & 5 & 0.07381 \\
Refinery cost & $B_{4}$ & 3 & 5 & 0.07381 \\
Financial support & $B_{4}$ & 4 & 6 & 0.061905 \\
Public health & $B_{4}$ & 4 & 6 & 0.061905 \\
Tourist satisfaction & $B_{4}$ & 4 & 6 & 0.061905 \\
Water cost & $B_{4}$ & 5 & 7 & 0.047619 \\
Damage to land & $B_{4}$ & 5 & 7 & 0.047619 \\
Stakeholder acceptance & $B_{4}$ & 5 & 7 & 0.047619 \\
Return on investment & {$\left[B_{3}, B_{5}\right]$} & 3 & 8 & 0.035714 \\
Public acceptance & {$\left[B_{3}, B_{5}\right]$} & 3 & 8 & 0.035714 \\
Ecological impact & {$\left[B_{3}, B_{5}\right]$} & 4 & 9 & 0.02381 \\
Environmental risk & {$\left[B_{3}, B_{5}\right]$} & 4 & 9 & 0.02381 \\
Recreation tourism & {$\left[B_{3}, B_{5}\right]$} & 4 & 9 & 0.02381 \\
Environmental policy & {$\left[B_{3}, B_{5}\right]$} & 5 & 10 & 0.009524 \\
Political acceptance & {$\left[B_{3}, B_{5}\right]$} & 5 & 10 & 0.009524 \\
Consistency with & {$\left[B_{3}, B_{5}\right]$} & 5 & 10 & 0.009524 \\
policies & & & & \\
\hline
\end{tabular}

